\title{
We cannot afford an AIDS epidemic
}

\author{
Steven Dodwell
}

I remember her so well. It was the summer of 1985 and I was a student in the department of medicine. Everyone was baffled-pyrexia and diarrhoea in a wasted young lady with generalised lymphadenopathy. We ran practically every test the laboratory could offer-multiple blood, urine, and stool samples, lumbar punctures, $x$ ray examinations, bone marrow trephines, and aspirates, lymph node biopsy. She suffered in uncomplaining silence. But on going back over her history the fact that her husband was a long distance lorry driver took on a sinister new significance in the light of recent developments in the medical scene in neighbouring countries. A new blood test had become available at our blood transfusion centre. It was done; she was positive.

Since then I have lost count of the innumerable computerised result slips "HIV 1 antibody test-positive" that I have seen. I recall a few of the faces behind the slips. Twins, one healthy, bouncing, and vital; the other wasted and miserable with hepatosplenomegaly and recurrent chest infections. The woman who burst into tears when I confirmed that she was pregnant. Startled by her reaction, I heard her tragic story-how first one of her children then the other had become ill and would not get better. On taking them to the hospital she had been told that they both had AIDS and that she was seropositive. Shortly afterwards both children died. Weeping, she told me she could not bear to watch another child die. There was the prominent businessman and town councillor who was brought by his puzzled, worried relatives. They told me that he had been behaving most bizarrely for the previous few days. A tremor was noticed, which steadily grew worse along with his HIV dementia until he died, an enfeebled mind in a violently uncontrollable body. Once she was a pretty young girl, now a skeletal remnant of her former self, afflicted with terrible diarrhoea -20 motions a day or more. Reviewing my memories of just a few short months, what a gallery of suffering I visit.

And now some figures. Perhaps $1 \cdot 2$ million people are HIV positive in my small country now. Twenty seven per cent of young men living in urban areas and working in industry were found to be positive by our blood transfusion service when it was seeking donors. Thirty nine per cent of the new army recruits in a recent intake were positive. Twenty five per cent of medical inpatients were found to be positive in a central hospital. A professor of medicine, responsible for running the HIV clinics at a hospital in the capital, stated that at current death rates a half of the population between the ages of 20 and 40 would die in the next five years.

My mind leapt ahead to the nightmare scenario that his words had conjured up. The young, bright, urban, wage earning population savagely reduced, tax income for the government severely curtailed. This would mean that education, health, and other service ministries would suffer and the industrial and commercial sector would lose skilled labour and educated minds. Not only that, but in our non-welfare state, with the extended family so much an important economic part of life, there would be no more school fees, no more university education for a generation of children. Aged parents and grandparents would hear of their pride and joy, their insurance policy, dying of HIV dementia or pulmonary Kaposi's sarcoma in some hospital far from home.

\section{...This is the way the world ends-not with a bang but with a whimper.}

T S ELIOT

What kind of shrivelled wasteland will my nation become? Young orphans and the old ekeing out a crabbed, hand to mouth existence in dusty, forgotten rural homes, while in the towns, industry falls silent, businesses and stores lie closed and derelict while the wind blows rubbish and old leaves down deserted, dead streets.

This epidemic goes on. In part, the promiscuity of this nation is due to the colonial system of the past where rural men, forced to fit into the new economic order, travelled to the towns for work, leaving wives and family behind. Generations of men have lived and worked a lifetime, seeing their families but once a year. A survey by a university department here showed that young men in the capital have up to 50 or more different sexual partners a year. More than 900000 people were treated for sexually transmitted disease in this city the year before last - many may have been repeats, but many more were treated by private practitioners or traditional healers and thus did not appear in the figures. Prostitutes at some of the city's taverns report up to 10 different contacts a night. At many of these places their liaisons take place standing, with a diamond mesh wire fence between the two participants to protect the prostitute from violence to her person or robbery of her earnings.

Why does this epidemic go on? Why does this nation die so quickly, so silently? Because of a conspiracy of silence. Directives that HIV was not to be put on a death

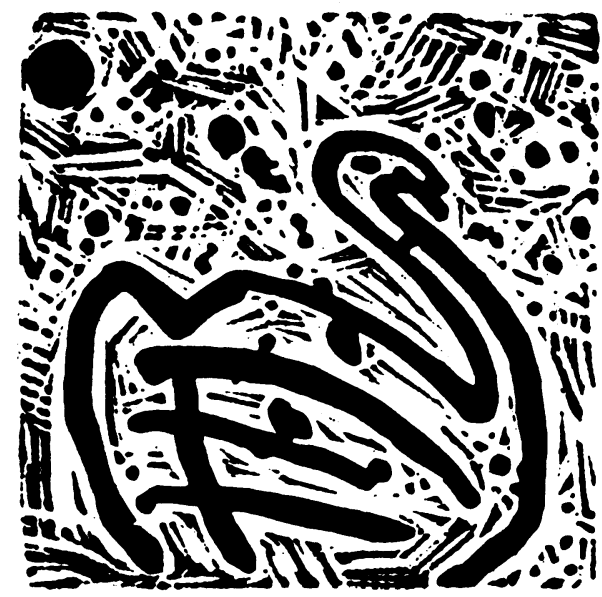

certificate as a cause of death were issued. Educational materials for schools and the armed forces were mysteriously held up at the government printers for more than two years. A moratorium was declared on research and publication. Little information is available to the public and what is available is couched in clumsy, learned language that most educated laymen would have trouble with, never mind the humbler of our citizens. There is no recourse to controlled mediatelevision, radio, and newspapers are all under tight government supervision. Among the medical profession there has been either fear and despair for the future or there has been denial. A district medical officer told me of one of the few health teams sent out from the Ministry of Health to his area. The health educators spent their days showing films, doing dramas, disseminating information, and their nights sleeping with the local girls. Medical students in the medical residence, supposedly well educated and constantly seeing patients with AIDS on teaching rounds, still maintain two or three sleeping partners at any one time. Well known people and community leaders have died already of HIV-but the conspiracy of silence has ensured that those deaths were wasted in terms of their warning value. And whispers of the possibility of a cure worry us. What if the cure is available only in the West and only at high cost? Suddenly our foreign exchange will be gone, used in the service of those in power and their contacts. Our health budget is already overstrained and often inappropriately spent. We cannot afford an AIDS epidemic. But one is already upon us. So far it has been the silent epidemic-healthy, asymptomatic carriers spreading seropositivity far and wide. Now the symptoms begin and a nation slowly withers and dies.

Steven Dodwell is a junior doctor in a central African country ${ }^{\star}$

$\star$ This is not the doctor's real name 